Jakub Maciej Łubocki

ORCID: 0000-0002-1957-0682

Muzeum Narodowe we Wrocławiu

\title{
Funkcje okładek dokumentów muzycznych w perspektywie okładkoznawstwa*
}

Abstrakt: Koncepcja okładkoznawstwa jako multidyscyplinarnego obszaru badawczego jest w Polsce stosunkowo młoda, mimo że badania z tego zakresu były już prowadzone. Artykuł jest rozwinięciem niektórych tez $\mathrm{z}$ wcześniejszych prac autora, a także pierwszą próbą opisu okładek dokumentów muzycznych w perspektywie bibliologicznej (rozpoznającej okładkę jako ochronę dokumentu, dostosowaną do jego formy, treści, przeznaczenia i pochodzenia, o swoistych funkcjach i konstrukcji) i okładkoznawczej (jako wytwór wydawniczy o specyficznych cechach edytorsko-estetycznych, historycznych, kulturowych, społecznych i semiotycznych nastawionych na wywołanie konkretnej reakcji u odbiorcy). Dokonany przegląd funkcji okładek dokumentów muzycznych przedstawia korzyści płynące z badań nad nimi oraz pozwala zadać pytanie, czy okładki dokumentów muzycznych przejawiają swoiste funkcje, nieznane wśród innych typów dokumentów.

Słowa-klucze: okładki nut, okładkoznawstwo, dokumenty muzyczne, okładki

\section{Wstęp. Korzyści z badania okładek dokumentów muzycznych}

Okładki dokumentów muzycznych, jak też innych dokumentów związanych z muzyką, wciąż czekają na większe zainteresowanie naukowe, mimo że są bogatym źródłem wiedzy. Świadczą o tym choćby spostrzeżenia Renaty Tańczuk ${ }^{1}$ czy Pawła Banasia ${ }^{2}$, za którymi można podać, że okładki tego rodzaju mogą wspierać badania nad:

* Materiał ilustracyjny do odwołań umieszczonych w tekście artykułu zamieszczono na stronie Ilustracje do artykulu „Funkcje okładek dokumentów muzycznych $w$ perspektywie okładkoznawstwa", https://issuu.com/jmlubocki/docs/jmlubocki_okladki.

1 R. Tańczuk, Od kolekcji do wystawy, [w:] Obrazki z nut. Druki muzyczne od końca XIX do potowy XX wieku z kolekcji Pawła Banasia. Wystawa w Dolnoślaskiej Bibliotece Publicznej im. Tadeusza Mikulskiego we Wrocławiu. Styczeń/luty 2018, [kat. wystawy] red. J. Czarnik, A. Ćwik, Wrocław 2018, s. 11-12.

2 P. Banaś, W ogrodzie nut, [w:] Obrazki z nut, s. 3-10. 
— rozwojem sztuki drukarskiej,

- rolą obrazu w reklamowaniu i popularyzowaniu muzyki,

— stanem popularnej kultury muzycznej,

- rozwojem ruchu „domowego muzykowania” i innych lekkich form obcowania z muzyką (variétés, kabarety, kinoteatry),

- przemianami obyczajowymi, społecznymi i technologicznymi.

Nuty, przez swoją masowość (drukowane niekiedy w setkach tysięcy egzemplarzy), były bardzo łatwo dostępne dla swoich potencjalnych użytkowników, a utylitarność wpisana $\mathrm{w}$ ich naturę (w przeciwieństwie do - przynajmniej niektórych rodzajów - książek) sprawiała, że można było pozwolić sobie na zaopatrzenie ich w okładki mniej nobliwe, tradycjonalistyczne czy zachowawcze. Szybciej też odzwierciedlały przemiany, na przykład w modzie, gdyż ich proces wydawniczy był zdecydowanie krótszy — niektóre nuty ukazywały się drukiem już w dniu premiery utworu lub tuż po niej. Maurice Rickards wskazuje, że twórcy dziewiętnastowiecznych okładek dokumentów muzycznych robili wszystko, by jak najlepiej oddawać tematykę utworów wówczas popularnych, i wymienia różne rodzaje okładek: romantyczne, historyczne, wojenno-patriotyczne, narodowe, religijne, humorystyczne czy powstałe z okazji szczególnie doniosłych wydarzeń. Jednak najobficiej według Rickardsa było reprezentowane społeczeństwo ${ }^{3}$ : nuty najczęściej ilustrują postaci, a przez nie aktualną modę, sposoby rozrywki, modele podróżowania itp. Stają się więc okładki nut utrwalonym znakiem chwili, przezroczem, na którym możemy oglądać daną epokę jak żywą. Jak ciekawe badania można prowadzić nad okładkami nut, świadczy praca Eliasa S. Cohena i Anny L. Kruschwitz, w której przeanalizowano popularną muzykę amerykańską, opublikowaną w latach 1830-1980, pod kątem popularnych poglądów i odczuć na temat starzenia się i starości. Na podstawie prywatnej kolekcji ponad 300 druków muzycznych związanych ze starzeniem się badano dwie formy reprezentacji nastrojów społecznych: teksty utworów i właśnie okładki ${ }^{4}$. W Polsce także zaczęto dostrzegać wartość płynącą z badań okładek tego typu dokumentów, czego przykładem jest praca Marcina Zglińskiego ${ }^{5}$.

Badania okładek dokumentów muzycznych mogą jednak być narażone na niepełność, powierzchowność, tracić szerszą perspektywę, skupiając się wyłącznie na wąsko zakreślonym aspekcie narzucanym przez daną dyscyplinę czy kierunek

3 M. Rickards, The Encyclopedia of Ephemera. A guide to the fragmentary documents of everyday life for the collector, curator, and the historian, red. M. Twyman, współudz. S. du Boscq de Beaumont, A. Tanner, London 2001, s. 293.

${ }^{4}$ E.S. Cohen, A.L. Kruschwitz, Old age in America represented in nineteenth and twentieth century popular sheet music, „The Gerontologist” 30, 1990, nr 3, s. 345-354. W konkluzji artykułu stwierdzono, że znaczna większość tych form przedstawia raczej negatywne niż pozytywne opinie na temat starzenia się i starości.

5 M. Zgliński, The cover design of Polish propaganda songs, 1945-1955, [w:] Music, Politics and Ideology in the Visual Arts, red. P. Gancarczyk, D. Grabiec, Warszawa 2015, s. 139-151. 
badawczy. Prowokuje to w bibliologach — badaczach komunikacji dokonywanej za pomocą uniwersum dokumentów — refleksję, aby patrzeć na okładki (w tym okładki dokumentów muzycznych) w sposób kompleksowy: przez pryzmat funkcji pełnionych w procesie komunikacji. W tym celu proponuję rozpatrywać wszelkie okładki w ramach odrębnego kierunku badawczego — okładkoznawstwa. Ta propozycja badawcza opisana i nazwana wprost została stosunkowo niedawno ${ }^{6}$, mimo że historia samych badań nad okładkami poświadczona wynikami badań, także w Polsce, jest dość długa i sięga połowy XX wieku ${ }^{7}$.

\section{Podstawowe problemy okładkoznawstwa ${ }^{8}$}

Okładki różnych typów dokumentów rozpatruje się zazwyczaj w jednej z następujących perspektyw: 1. edytorskiej/materialnej (okładka jako produkt rzemieślniczy lub przemysłowy), 2. estetycznej/przestrzennej (okładka jako źródło doznań estetycznych), 3. komunikacyjnej/społecznej (okładka jako kulturowy komunikat nadany od nadawcy do odbiorcy o świadomie ukształtowanej treści), 4. związków z dziełem, jego treścią i formą (okładka jako emanacja przekazu dzieła w nią obłożonego i jednocześnie dzieła utrwalonego na konkretnym nośniku). Pierwsze trzy perspektywy są stosunkowo wąskie i skupiają się wyłącznie na wybranym aspekcie okładki: materialna ocenia tylko sposób wykonania okładki (warsztat, technologia, materiał); przestrzenna ocenia obiektywne i subiektywne cechy estetyczne, na które składają się styl okładki (wyznaczający przynależność do kierunków artystycznych właściwych danej epoce, miejsca, kręgu kulturowego itp.), struktura

${ }^{6}$ Artykuł jest rozwinięciem tez zawartych w J.M. Łubocki, Okładka jako część dokumentu na przykładzie plyty gramofonowej w ujęciu bibliologicznym, Wrocław 2017, s. 73-101; idem, Okładki druków muzycznych jako ważne zagadnienie badawcze: na marginesie wystawy Obrazki z nut (Wrocław, 19 stycznia-28 lutego 2018), „Studia o Książce i Informacji” 2018, nr 37, s. 215-219. Najpełniejsze przedstawienie koncepcji okładkoznawstwa zob. J.M. Łubocki, Okładkoznawstwo stare zagadnienie, nowa koncepcja badawcza, „Zagadnienia Rodzajów Literackich” 63, 2020, z. 3, s. 61-78.

7 Stwierdzam to na podstawie dat wydań publikacji prac takich, jak: W. Eule, Ein Jahrhundert Verlagseinband. Wandlungen des Einbandschmucks, „Archiv für Druck und Papier” 1961, nr 7, s. 158-166; V. Sack, Verlegereinbände und der Buchhandel Peter Schöffers, „Archiv für Geschichte des Buchwesens" 13, 1972, s. 249-288; J. Dunin, Rozwój cech wydawniczych polskiej ksiązki literackiej XIX-XX wieku, Łódź 1982 (rozdz. 7. Okładka i obwoluta); idem, Pismo zmienia świat. Czytanie. Lektura. Czytelnictwo, Warszawa 1998 (rozdz. 14. Okładki, obwoluty $i$ wystawy ksiażek w komunikacji literackiej); idem, Oktadka i obwoluta jako komunikat. Wprowadzenie do problematyki, [w:] Sztuka książi. Historia - teoria - praktyka, red. M. Komza, Wrocław 2003, s. 83-90; M. Lachman, Okładkowy stan posiadania (w literaturze najnowszej), „Teksty Drugie” 2012, nr 6, s. 101-117; eadem, Nie(d)ocenione ustugi oktadki, [w:] Stolice i prowincje kultury. Ksiega jubileuszowa ofiarowana prof. Alinie Kowalczykowej, red. J. Brzozowski, M. Skrzypczyk, M. Stanisz, Warszawa 2012, s. 566-584.

${ }^{8}$ W tym podrozdziale rekapituluję główne elementy wywodu z: J.M. Łubocki, Okładkoznawstwo. 
graficzna okładki (Gestalt projektu, wyznaczona przez ogólne prawidła wizualne projektu graficznego) oraz artyzm okładki (odwołujący się do subiektywnych wrażeń estetycznych i dorobku jej artysty-wykonawcy); komunikacyjna bada, jak płaszczyzna znaków i symboli, jaką jest okładka, formuje przekaz informacyjny (bezinteresowny) i sterujący (marketingowy, świadomie wykorzystujący przekaz jako narzędzie propagandy i perswazji). Natomiast ostatnia perspektywa bada okładkę jako całość: utrwalony materialnie i ucieleśniony przestrzennie komunikat społeczny, ewokujący treść i sens dzieła na zewnątrz dokumentu.

Perspektywy te wynikają z obszaru macierzystej dyscypliny, w której obrębie badania okładkoznawcze są prowadzone. Badania prowadzone z perspektywy materialnej, przestrzennej lub społecznej są badaniami autonomicznymi nad okładkami, a więc pomijają zagadnienie dzieła, które okładka ochrania. Korzystają one przede wszystkim z metod i teorii oprawoznawstwa, introligatorstwa, edytorstwa, typografii, nauki o sztuce (w tym sztuce książki), grafice i estetyce, nauki o komunikacji, medioznawstwa, bibliotekoznawstwa, nauki o bibliografii czy marketingu. Z kolei badania związków okładki z dziełem wymagają skorzystania $\mathrm{z}$ metod i teorii nauk badających poszczególne gatunki wypowiedzi (treść dzieła) oraz typy dokumentów (forma dzieła). Stąd badania takie wykorzystują między innymi metody i teorie księgoznawstwa, prasoznawstwa, literaturoznawstwa, naukoznawstwa czy muzykologii. Katalog tych nauk nie jest zamknięty: na temat okładek różnych typów dokumentów może wypowiedzieć się na przykład kartografia (atlasy i mapy) czy filmoznawstwo (filmy), a kolejne typy dokumentów i gatunków wypowiedzi implikują potrzebę wkraczania na coraz to nowe obszary badawcze. Możliwe jest także stosowanie kilku metod, łączących badania autonomiczne $\mathrm{z}$ badaniami związanymi $\mathrm{z}$ dziełem.

Takie zróżnicowanie perspektyw powoduje rozproszenie wyników badań. Jest to stan niekorzystny, albowiem okładki, choć różnorodne, powstają, funkcjonują i przekazują komunikaty w podobny sposób, stąd propozycja badań kompleksowych, dla których odpowiednią przestrzeń w uniwersum nauk tworzy okładkoznawstwo. Zakres badań okładkoznawczych wyznacza definicja okładki oraz jej relacja do definicji oprawy. Definicje terminów „oprawa” i „okładka”, które potocznie często są używane zamiennie, są różne, a różnice między nimi nieostre i wypływają z różnych poglądów na stosunek, jaki łączy okładkę i oprawę ${ }^{9}$. Z wszystkich jednak wynika, że zadaniem okładki jest ochrona dokumentu oraz jego scalenie. Bez tych dwóch cech, w świetle definicji, nie można mówić o okładce. Implikuje to pewien problem, jako że nie tylko okładki chronią i ujmują w całość dokument - czynią to także inne obiekty (dawniej na przykład kapsy, dziś choćby skoroszyty), a więc ochronność i scalenie względem dokumentu nie może być cechą konstytutywną okładki. Jednak nie każda okładka pełni funkcję

9 Wniosek ten wypływa z analizy przedstawionej w J.M. Łubocki, Okładka jako część dokumentu..., s. 77-83, 101-102. 
ochronną lub scalającą dokumentu. Istnieją takie „okładki”, które powinny być rozpatrywane przez okładkoznawstwo, a które jednak w kontekście podanej definicji okładkami nie są. Mówimy tu o „okładkach” dokumentów elektronicznych (które są udostępniane użytkownikowi zdalnie, na ekranie, a więc ochrona tych dokumentów w sensie fizycznym polega na ochronie danych, a nie samego nośnika) oraz „okładkach” dokumentów pozbawionych typowego bloku (na przykład w czterostronicowych dokumentach złożonych wyłącznie z jednego arkusza papieru pierwsza strona jest jednocześnie „okładką”, która nie scala dokumentu ani też go nie ochrania). Tego rodzaju przypadki można nazywać zwierciadłami okładki, albowiem choć nie są okładkami w pełni znaczenia tego słowa, to pełnią większość ich funkcji i są kształtowane jak one. Z kolei podobiznami okładek można nazywać reprodukcje okładek w miejscu innym niż sam dokument (na przykład wizerunek okładki na billboardzie).

Tak określone okładkoznawstwo może być dzielone dalej, na okładkoznawstwa konkretnych typów według już wskazanych ujęć: okładkoznawstwo książkowe, prasowe, muzyczne, komiksowe itp., ponieważ każdy typ dokumentu odmienia nieco funkcje i cele jego okładki, a to powoduje różnice metodologiczne i terminologiczne. Zważywszy na to, okładkoznawstwo w pewnym sensie się dzieli, jednak nie w sposób nieprzekraczalny czy trwały. Więcej — badacze zajmujący się okładkami różnych typów dokumentów powinni dążyć do wymiany wyników badań i zawsze uwzględniać stopień tożsamości lub odmienności jednego typu od innego. Innymi słowy - uwzględniać pewien stopień syntezy i dążyć do uogólnienia, gdyż tylko okładkoznawstwo łączące będzie w stanie zwrócić uwagę na aspekty pomijane w izolowanych analizach konkretnych typów. W przeciwnym razie badania nad okładkami będą mieć cząstkowy charakter, obejmując tylko wycinek zagadnienia i nie poszerzając wiedzy na jego temat, jak dzieje się to współcześnie.

Trudno w tej chwili wyrokować, jakie będą losy nakreślonej koncepcji i czy na stałe wpisze się w krajobraz badań nauk społecznych i humanistycznych, spróbujmy jednak zaaplikować postulowane tu wzorce do analizy funkcji okładek dokumentów muzycznych.

\section{Funkcje okładek dokumentów muzycznych w perspektywie okładkoznawstwa}

Okładki są najbardziej interesujące poznawczo, gdy uchwyci się ich zróżnicowanie funkcjonalne oraz interferencje powstające między różnymi funkcjami, jakie odnajdujemy w jednym elemencie danej okładki. Ujęcie funkcjonalne wskazuje na wspólny cel, funkcjonowanie i oddziaływanie okładek — także ze 
względu na specyficzny sposób, w jaki komunikujemy się za ich pomocą ${ }^{10}$. Zawsze więc istotnym elementem badań nad okładkami jest rozpoznanie ich funkcji. Okładkoznawstwo dzieli funkcje na trzy stopnie. Funkcje I stopnia to takie, które można uogólnić na okładki wszystkich typów dokumentów - występują w prawie każdej okładce, niezależnie od typu dokumentu, do którego są dołączone; funkcje I stopnia w różnych okolicznościach mogą się krzyżować lub potęgować, tworząc funkcje II stopnia, występujące rzadziej i mniej „obowiązkowo”, a niektórych z nich dla pewnych typów okładek w ogóle nie da się ich wskazać; funkcje III stopnia wykrystalizowały się z funkcjonowania konkretnego typu dokumentu i nie przejawiają się w innych typach.

\subsection{Funkcje I stopnia okładek dokumentów muzycznych}

Funkcje I stopnia to: ochronna, in formacyjna (z mocnym walorem identyfikującym/bibliograficznym), estetyczna, reklamowa i perswazyjna (przybierająca $\mathrm{w}$ pewnych okolicznościach charakter manipulacji przekazem na potrzeby jakiejś ideologii). Rickards, opisując ogół okładek dokumentów muzycznych, podał ich cechy, które uznał za szczególnie ważne, a w których okładkoznawstwo rozpoznałoby realizację funkcji estetycznej (il. 1) i perswazyjnej (il. 2):

Ilustrowana okładka nut, która pojawiła się jako gatunek na początku XIX wieku, wkrótce stała się szeroko zróżnicowanym nośnikiem sztuki popularnej. Oprócz plakatu, który powstał nieco później, żaden inny typ dokumentu życia społecznego nie zapewniał artystom tak wielu możliwości tematycznych. W czasach swojej świetności w drugiej połowie XIX wieku okładki nut musiały mieć tak samo duży wpływ na sklepy muzyczne i domostwa jak okładki płytowe sto lat później. Ówczesne przedstawienia sklepów wydawców muzycznych — niektóre z nich zostały wprost wydrukowane na okładkach nut — pokazują okładki wystawione w każdej witrynie; niektóre katalogi wydawców muzycznych zwracały szczególną uwagę na fakt zilustrowania okładki nawet jeszcze w XX wieku ${ }^{11}$.

Rickards wskazuje także na większą niż w innych dokumentach wagę i ilość danych bibliograficznych pojawiających się na okładkach niektórych dokumentów muzycznych:

[Okładki dokumentów muzycznych] są czasami nazywane muzycznymi stronami tytułowymi, ponieważ eksponują co najmniej tytuł utworu, nazwisko kompozytora i wydawcę. W wielu wypadkach zawierają nazwisko autora słów, informację, gdzie można nabyć dany dokument, dedykację, wykaz innych publikacji w serii, metrykę drukarską i cenę. We wczesnych przykładach [okładek dokumentów muzycznych] czasami dołączony jest numer katalogowy wydawcy (numer katalogowy płyty). Dane te mogą być wydrukowane jako pierwsza strona dokumentu, więc

10 Zob. B. Hojka, Okładka książkowa z perspektywy komunikacyjnej, [w:] W poszukiwaniu odpowiedniej formy. Rola wydawcy, typografa, artysty i technologii w pracy nad ksiażka, red. M. Komza, współudz. E. Jabłońska-Stefanowicz, E. Repucho, Wrocław 2012, s. 62. Także J.M. Łubocki, Oktadka jako część dokumentu..., s. 128-129.

11 M. Rickards, op. cit., s. 291, przeł. - J.M.Ł. 
można stwierdzić, że służą zarówno jako strona tytułowa, jak i okładka. Ściśle rzecz ujmując, niektóre z nich okładkami nie są, ponieważ zostały wydrukowane wraz z innymi stronami nut na tym samym arkuszu ${ }^{12}$.

Okładkoznawstwo dostrzeże w tym fakcie szczególną istotę funkcji informacyjnej okładki dokumentów muzycznych (il. 3a-b), wypływającą z ich morfologii. Spostrzeżenie to potwierdza także wniosek, że okładkoznawstwo powinno rozpatrywać nie tylko okładki rozumiane dosłownie, jako fizyczna ochrona i ujęcie dokumentu (jak chcą tego definicje), ale także te elementy, które pełnią funkcje okładek, a jednak nie wypełniają definicji okładki: wspomniane już zwierciadła i podobizny okładek.

\subsection{Funkcje II stopnia okładek dokumentów muzycznych}

Najważniejszą funkcją II stopnia jest funkcja desygnująca: to między innymi dzięki okładce wiemy, że mamy do czynienia z publikacją nutową, a nie na przykład z płytą czy czasopismem; funkcją tą można także manipulować, jeśli okładka przedmiotu udaje dokument, którym nie jest. Ponieważ dokument muzyczny ma swoisty katalog struktur i treści, które oznaczają, że w środku znajduje się dokument muzyczny, a nie na przykład kartograficzny, funkcja desygnująca jest $\mathrm{w}$ ich przypadku możliwa do zrealizowania (il. 4a-f). À rebours istnieją także przedmioty, które swoją okładką sugerują zawartość nutową, a w istocie nie zawierają materiału muzycznego (il. 5).

Druga funkcja to funkcja opakowaniowa: okładka jest opakowaniem $\mathrm{w}$ warunkach pełnego utowarowienia dokumentu w ramach wolnego rynku pomaga w jego dystrybucji (na przykład przez naniesienie na nią kodu kreskowego), promuje produkt i jest narzędziem marketingowym (opakowanie, obok produktu, ceny, miejsca sprzedaży i promocji, stanowi klucz do skutecznej transakcji). Funkcja ta także przejawia się w okładkach dokumentów muzycznych (il. 6a-b). Choć funkcja ta wydaje się tożsama z funkcją ochronną, to jednak nie jest $\mathrm{z}$ nią identyczna, gdyż nie każda okładka, która chroni, staje się automatycznie opakowaniem. Tym samym nie każdą okładkę (w tym okładkę dokumentu muzycznego) można traktować jak opakowanie w sensie marketingowym.

12 Ibidem, przel. - J.M.Ł., oryg.: „The items discussed here are sometimes called music titlepages, because they display, at the very least, the title of the work, the name of composer, and the publisher. In many cases they include the name of the writer of the words, information about where copies might be obtained, a dedication, a statement about other publications in the series, a printer's imprint and a price. Early examples may include a publisher's number (plate number). They are printed as the front page of a publication and can therefore be said to serve as both titlepage and cover. Strictly speaking some are not covers, since they were printed on the same sheet as one of more pages of the music". 
Funkcja trzecia - nobilitująca ${ }^{13}$ — wynika z nałożenia się funkcji desygnującej i opakowaniowej: okładka a priori nadaje pewien status treści, którą przechowuje. Oddziaływanie tej funkcji niekiedy rozszerza się także na użytkownika dokumentu. Funkcja ta również podatna jest na manipulację: gdy ktoś celowo pokazuje się z nutami (na przykład wybitnego kompozytora), jednak bez zamiaru grania $\mathrm{z}$ nich ${ }^{14}$. Funkcję tę obserwuje się na przykład wtedy, gdy dziełu pomieszczonemu na nośniku nieksiążkowym użytkownik nadaje kształt książkowy przez oprawienie, ponieważ pierwotne medium (na przykład gazeta, broszura, nadbitka, kserokopia) jest niewystarczające do optymalnego odbioru treści ${ }^{15}$. Funkcja nobilitująca tylko w pewnej części może być realizowana przez okładkę dokumentu muzycznego: jeśli jej przeniesienie na użytkownika dokumentu jest możliwe, to odnośnie do dokumentów muzycznych częściej obserwujemy ich destrukcję niż nobilitację - najczęściej przystosowuje się je do użycia podczas gry na instrumencie, a więc także wygody. Wobec tego elementy introligujące czy ochronne bardziej przeszkadzają niż pomagają: o ileż łatwiej przecież grać z pojedynczych stronic złożonych w leporello niż ze źle zszytego woluminu, który notorycznie zamyka się na pulpicie. O wiele częściej więc możemy wyobrazić sobie rozcięcie zszytego woluminu do pojedynczych stron lub pozostawienie kserokopii utworu w luźnych kartkach bez oprawy niż jego dodatkowe nią utrwalenie.

Jeśli okładka jest ściśle powiązana $\mathrm{z}$ treścią, z połączenia funkcji informacyjnej, estetycznej i perswazyjnej może wykształcić się dodatkowa funkcja programująca ${ }^{16}$ : okładka może wpływać na postrzeganie i odbieranie treści

13 Dotychczas w swoich pracach określałem tę funkcję jako wartościująca. Jednak na podstawie słusznej sugestii redakcji, że jest to określenie mylące (gdyż nie chodzi tu o wartość, lecz o status), wprowadzam tu określenie nobilitująca.

14 Czasy, w których zjawisko to występuje, Magdalena Lachman opisuje tak: „coraz częściej się z książkami pokazujemy, niż je czytamy, i gdy zaczynamy cenić w nich sam materialny kształt, stopień zużycia okładek wiele mówi o naszych książkowych predylekcjach”, eadem, Nie(d)ocenione ustugi oktadki, s. 569.

${ }^{15}$ Ibidem, s. 569-570. Autorka zauważa jeszcze jeden ważny aspekt nośnika, na jakim wydano treść: gazety, druki ulotne czy dodatki uchodzą za nośniki efemeryczne, przeznaczone do krótkotrwałego czy nawet jednorazowego użytku; tym samym są ,traktowane jako mniej nobliwe niż książki”. W ten sposób parametry formalne tych wydawnictw mogą przesądzać o ich odbiorze i ocenie. W literaturoznawstwie taki pryzmat może wpłynąć na postrzeganie znaczenia utworu, a w bibliologii — na fakt jego ewidencji w katalogu bibliotecznym lub bibliografii. Nadanie tego typu drukom oprawy może więc uchronić je przed pochopnym zdeprecjonowaniem i zdyskredytowaniem.

16 Dotychczas w swoich pracach określałem tę funkcję jako interpretacyjna. Jednak na podstawie słusznej sugestii recenzyjnej, że jest to określenie zbyt szerokie, wprowadzam tu określenie programująca, albowiem interpretowanie to nie tylko proces wykonywania pewnej dyrektywy wykonawczej narzucanej przez okładkę odbiorcy. To także okładka sama w sobie jest już interpretacją: wizją projektanta okładki, czyli namacalnym znakiem rozumienia sensów dzieła przez empirycznego odbiorcę (projektanta, ale także i wydawcy, a nawet autora dzieła, jeśli miał realny wpływ na kształt okładki). Następnie kolekcjoner i badacz okładek może je jeszcze różnicować pod kątem zbieżności i/lub kompatybilności znaczeń interpretacyjnych zawartych na okładkach (czy graficzne 
dzieła, programować jego przekaz, determinować technikę na przykład czytania, rzutować na recepcję w ogóle: „przez swoje »wychylenie« ku odbiorcy okładka może sterować recepcją albo chociaż odbijać właściwe jej prawidłowości. W tym przypadku nie do przecenienia jest zarówno oddziaływanie rozmaitych efektów wizualnych oraz rozwiązań typograficznych, jak też siła perswazyjna werbalnych komponentów okładki" ${ }^{17}$. Często funkcja ta jest świadomie wykorzystywana do wzmocnienia odbioru komunikowanego dzieła lub gwarantowania jego autentyczności (najbardziej wtedy, gdy okładki są projektowane przez samych autorów lub za ich sugestiami), jednak ma to swój negatywny wydźwięk, jeśli komunikat okładkowy stoi w sprzeczności z intencjami autora co do wydźwięku jego dzieła; wątpliwe jest to również wówczas, gdy dzieło wieloznaczne, o wielu możliwych interpretacjach, jest zaopatrzone w okładkę, która promuje tylko jedną z nich, co może spłycić odbiór dzieła. Funkcja ta może też przejawiać się w formie cytatu, który odnosi treść dzieła do innego tekstu kultury — ten aspekt funkcji pojawia się w okładkach będących kopią, parafrazą, pastiszem, parodią, trawestacją lub w inny sposób przetwarzających jakiś samodzielny obraz lub inną okładkę. Cytaty takie potrafią przybierać formę inteligentnej gry z odbiorcą, kryjącej wiele znaczeń, podtekstów i niuansów. Wydaje się, że funkcja programująca nie występuje w uniwersum dokumentów muzycznych: przekaz okładki, jej treść i ukształtowanie raczej nie wpływa na realizację treści dzieła, nie programuje jego odbioru, a już z pewnością nie determinuje techniki jego wykonania. Albowiem czy muzyk pod wpływem okładki zrealizuje dzieło inaczej? Na przykład pianista, napatrzywszy się na mroczną okładkę nut do Wlazt kotek na płotek, zamiast zagrać tę piosenkę żywo, wykona ją ponuro? Niemniej empiryczna próba odpowiedzi na to pytanie może być ciekawym eksperymentem badawczym.

Ostatnią funkcją wynikłą ze skrzyżowania funkcji informacyjnej i perswazyjnej jest funkcja adresująca. W swym podstawowym działaniu przejawia się ona we wskazaniu na okładce (tekstem lub grafiką), do kogo jest kierowana; staje się interesująca, gdy zacznie się nią manipulować: Janusza Dunina kusi eksperyment, aby Zbrodnię i karę Fiodora Dostojewskiego przedrukować w popularnej serii kryminałów i zaobserwować, jak wpłynie to na odbiór tego dzieła ${ }^{18}$. Z kolei Jan Muszkowski opisuje przypadek, gdy Tadeusz Boy-Żeleński opatrzył poważne

ujęcie dzieła jest zbieżne z jego utrwalonym w kulturze postrzeganiem, czy też wykracza poza nie, rozszerza/zawęża je itp.).

17 M. Lachman, Nie(d)ocenione ustugi oktadki, s. 574. Autorka przy okazji proponuje interesującą nowość edytorską, godną rozważenia i wprowadzenia w powszechnej praktyce edytorskiej: reprodukowanie okładek kolejnych wydań konkretnego dzieła w wydaniach krytycznych (,komentowanych"). Uważa, że byłoby to właściwe z literaturoznawczego punktu widzenia i nie można odmówić jej racji, jeśli żądamy, by literaturoznawcy nie popełniali grzechu „lekceważenia eksterieru książki” (za: J. Dunin, Pismo zmienia świat, s. 93).

18 J. Dunin, Pismo zmienia świat, s. 92. 
dzieło filozoficzne, które thumaczył, opaską z napisem: „Tylko dla dorosłych”19. Są to kolejne przykłady wpływu materialnej formy tekstu na jego odbiór. Funkcja adresująca jest również w pełni wykonalna odnośnie do dokumentów muzycznych (il. 7a-d). Okładka niekiedy informuje wprost lub wynika to z założeń serii (a serię reprezentuje swoista szata graficzna), że ochrania na przykład wydanie nut skierowane do osób uczących się, a więc na przykład z naniesionym palcowaniem, uproszczeniem materiału muzycznego lub też transponowaniem go do łatwiejszej tonacji.

\subsection{Funkcje III stopnia okładek dokumentów muzycznych}

Funkcje III stopnia są tak bardzo wyspecjalizowane na potrzeby jakiegoś typu dokumentu, że przejawiają się wyłącznie w okładkach tego typu. Funkcje tego stopnia mają między innymi okładki dokumentów dźwiękowych czy komiksów. Także wśród okładek dokumentów muzycznych możemy próbować doszukiwać się takich funkcji. Mogłaby nią być funkcja redagująca, będąca zwielokrotnieniem funkcji informacyjnej. Jak wiadomo, materiał muzyczny jednego kompozytora może ukazywać się w różnych redakcjach, różnym stopniu opracowania i/lub różnym stopniu wierności rękopisowi utworu. Oczywiście dzieje się to także w świecie książek, jednak tu można mówić jedynie o walorze identyfikującym funkcji informacyjnej, gdyż odmienności redakcyjne identyfikowane są przez osobę redaktora, względnie tłumacza, które są wymienione (lub nie) na okładce, co jest typową realizacją funkcji informacyjnej. Tymczasem w wypadku nut odmienności redakcji mogą być zespolone $\mathrm{z}$ domem wydawniczym lub nawet konkretną serią wydawniczą w taki sposób, że myślimy raczej o Das Wohltem-

19 J. Muszkowski, Życie książki, Kraków 1951, s. 186. Chodzi o Rozprawę o metodzie Kartezjusza, która ukazała się jako 45 tom „Biblioteki Boya”. Należy jednak oddać tłumaczowi, że w przedmowie do dzieła lojalnie wyjaśnił, że ,istotnie, książka ta nadaje się tylko dla dorosłych, ponieważ dla młodzieży jest zbyt poważna; ale wolę wyznać szczerze, iż, za pomocą tego niewinnego podstępu, pragnąłem wyzyskać moją reputacyę »gorszącego « pisarza, $i$, w niezawodnym sposobie, skłonić publiczność do przeczytania tego dziełka, skazanego, w zwyczajnych warunkach, na pleśnienia na półkach nielicznych bibliotek naukowych" (R. Descartes, Rozprawa o metodzie dobrego powodowania swoim rozumem i szukania prawdy w naukach, Kraków 1918, s. V-VI; pisownia oryginalna). Co symptomatyczne, egzemplarz, na podstawie którego uzupełniono informację Muszkowskiego ze zbiorów Biblioteki Narodowej (sygn. I 2.005.606 A; zob. Polona, http://polona.pl/item/2771632/0/ [dostęp: 7.07.2015]), jest już pozbawiony tej opaski i gdyby nie informacja w przedmowie, ten ważki element wystroju zewnętrznego zostałby całkowicie unicestwiony, a informacja o nim dochowana nie dłużej niż jedno pokolenie. Taka jest waga zachowywania dzieł w całości. Niestety od czasów Janusza Dunina nic się nie zmieniło i do dziś pokutuje błędne przekonanie bibliotekarzy, bibliofilów i introligatorów, że egzemplarz pozbawiony okładki jest kompletny, natomiast gdyby był pozbawiony choćby jednej strony, byłby traktowany jako zdefektowany; idem, Rozwój cech wydawniczych..., s. 133. 
perierte Klavier w edycji Petersa, a wręcz o Das Wohltemperierte Klavier w tej konkretnej szacie graficznej okładki (il. 8a-c), niż o osobie jej redaktora. Zdaje się, że takie zjawisko nie występuje w świecie innych dokumentów, albowiem nawet jeśli myślimy o wydaniu Pana Tadeusza w opracowaniu Stanisława Pigonia, to oczywiście słynna okładka serii wydawniczej „Biblioteka Narodowa” skojarzy się nam z tym opracowaniem. Jednak czy utożsamimy je z tą właśnie serią okładek? Wydaje się, że mniej niż w wypadku dokumentów muzycznych, choć jest to kwestia wymagająca dalszych badań.

\section{Podsumowanie}

Przed okładkoznawstwem jeszcze daleka droga do samodzielności. Wiele hipotez wymaga potwierdzenia, wiele obserwacji - naukowego opisu, wiele niewiadomych — wyjaśnień na drodze rzetelnych badań. Jednak pierwszy krok został już postawiony. Przykład niniejszej próby aplikacji teorii ogólnej w konkretnym obszarze - uniwersum dokumentów muzycznych — dowodzi, że można skutecznie stawiać następne kroki w dalszych kierunkach, aby na samym końcu tej drogi dojść do postulowanej nowej szkoły badawczej ${ }^{20}$; szkoły odpowiadającej na pytanie, które powinno stać się punktem wyjścia wszystkich badań okładkoznawczych: jak okładki funkcjonują w przestrzeni komunikacyjnej człowieka, jak wpływają na niego i jakie jest ich miejsce w badaniach nad dokumentem jako medium/narzędziem komunikacji. Tylko to pozwoli zrozumieć, dlaczego, mimo ery powszechnej cyfryzacji, a więc ery końca hegemonii fizycznych dokumentów, okładki nadal są (i prawdopodobnie będą). Pozwoli także docenić te zewnętrzne emanacje dokumentów, które do tej pory były często traktowane bez należytej uważności i dokładności.

\section{Functions of the covers of music documents in the perspective of cover studies (okładkoznawstwo)}

\section{Abstract}

The concept of ,cover studies” (Polish: okładkoznawstwo) as a multidisciplinary research field is relatively young in Poland, despite the fact that research in this field has been conducted earlier. The article extensing some of the theses from the author's earlier works, it is also the first attempt to describe the music-sheet covers from a bibliological perspective (as a protection of a document, adapted to its form and content with specific functions and structure) and cover studies (as a publishing product, with specific editorial, aesthetic, historical, cultural, sociological and semiotic features

20 Zob. J.M. Łubocki, Okładkoznawstwo, s. 75-76. 
aimed at evoking a specific reaction in the receiver). The overview of the functions of the musicsheet covers allowed to present the benefits of research on them and to ask the question whether this kind of covers has any specific functions, unknown to other types of documents (it has been shown that the answer requires further research).

Keywords: sheet-music covers, cover studies, okładkoznawstwo, covers, scores

\section{Bibliografia}

Banaś P., W ogrodzie nut, [w:] Obrazki z nut. Druki muzyczne od końca XIX do połowy XX wieku z kolekcji Pawła Banasia. Wystawa w Dolnoślaskiej Bibliotece Publicznej im. Tadeusza Mikulskiego we Wrocławiu. Styczeń/luty 2018, [katalog wystawy] red. J. Czarnik, A. Ćwik, Wrocław 2018, s. 3-10.

Cohen E.S., Kruschwitz A.L., Old age in America represented in nineteenth and twentieth century popular sheet music, ,The Gerontologist” 30, 1990, nr 3, s. 345-354.

Dunin J., Oktadka i obwoluta jako komunikat. Wprowadzenie do problematyki, [w:] Sztuka ksiażki. Historia - teoria - praktyka, red. M. Komza, Wrocław 2003, s. 83-90.

Dunin J., Pismo zmienia świat. Czytanie. Lektura. Czytelnictwo, Warszawa 1998.

Dunin J., Rozwój cech wydawniczych polskiej ksiązki literackiej XIX-XX wieku, Łódź 1982.

Eule W., Ein Jahrhundert Verlagseinband. Wandlungen des Einbandschmucks, „Archiv für Druck und Papier" 1961, nr 7, s. 158-166.

Hojka B., Okładka ksiązkowa z perspektywy komunikacyjnej, [w:] W poszukiwaniu odpowiedniej formy. Rola wydawcy, typografa, artysty i technologii w pracy nad ksiażka, red. M. Komza, współudz. E. Jabłońska-Stefanowicz, E. Repucho, Wrocław 2012, s. 61-72.

Lachman M., Nie(d)ocenione ustugi oktadki, [w:] Stolice i prowincje kultury. Ksiegga jubileuszowa ofiarowana prof. Alinie Kowalczykowej, red. J. Brzozowski, M. Skrzypczyk, M. Stanisz, Warszawa 2012, s. 566-584.

Lachman M., Oktadkowy stan posiadania (w literaturze najnowszej), „Teksty Drugie” 2012, nr 6, s. 101-117.

Łubocki J.M., Okładka jako część dokumentu na przykładzie płyty gramofonowej w ujęciu bibliologicznym, Wrocław 2017.

Łubocki J.M., Okładki druków muzycznych jako ważne zagadnienie badawcze: na marginesie wystawy Obrazki z nut (Wrocław, 19 stycznia-28 lutego 2018), „Studia o Książce i Informacji” 2018, nr 37, s. 215-219.

Łubocki J.M., Okładkoznawstwo - stare zagadnienie, nowa koncepcja badawcza, „Zagadnienia Rodzajów Literackich" 63, 2020, z. 3, s. 61-78.

Muszkowski J., Życie ksiażki, Kraków 1951.

Rickards M., The Encyclopedia of Ephemera. A guide to the fragmentary documents of everyday life for the collector, curator, and the historian, red. M. Twyman, współudz. S. du Boscq de Beaumont, A. Tanner, London 2001.

Tańczuk R., Od kolekcji do wystawy, [w:] Obrazki z nut. Druki muzyczne od końca XIX do połowy XX wieku z kolekcji Pawła Banasia. Wystawa w Dolnośląskiej Bibliotece Publicznej im. Tadeusza Mikulskiego we Wroctawiu. Styczé́/luty 2018, [katalog wystawy] red. J. Czarnik, A. Ćwik, Wrocław 2018, s. 11-12.

Sack V., Verlegereinbände und der Buchhandel Peter Schöffers, „Archiv für Geschichte des Buchwesens 13, 1972, s. 249-288.

Zgliński M., The cover design of Polish propaganda songs, 1945-1955, [w:] Music, Politics and Ideology in the Visual Arts, red. P. Gancarczyk, D. Grabiec, Warszawa 2015, s. 139-151. 
$* * *$

Jakub Maciej Łubocki — doktorant w Instytucie Informacji Naukowej i Bibliotekoznawstwa Uniwersytetu Wrocławskiego, badający zagadnienia komunikacji bibliologicznej (terminologia, normalizacja, języki informacyjno-wyszukiwawcze, ogólna teoria dokumentów, źródła informacji) oraz okładek dokumentów jako wieloaspektowego kanału komunikacyjnego. Pracownik Działu Sztuki Wydawniczej Muzeum Narodowego we Wrocławiu. Więcej zob. jmlubocki.wordpress.com. jakub.lubocki@mnwr.pl 